\title{
Mendesain Model Pembelajaran Sejarah Kebudayaan Islam (SKI) Berbasis Multikultural di Perguruan Tinggi
}

\author{
M. Hadi Masruri \\ Universitas Islam Negeri Maulana Malik Ibrahim Malang, Indonesia \\ hadimasruri@ymail.com
}

\begin{abstract}
This article seeks to offer a learning design of multicultural on History of Islamic Culture in Higher Education. These multicultural values include an attitude of self-respect, an attitude of respect for others, an attitude of respect for the environment and cultural nature, an attitude of appreciating beauty, an attitude of appreciating beauty, and an attitude of appreciating wholeness. The six values of multiculturalism are expected to be internalized in learning by lecturers of Islamic Cultural History courses in Higher Education in a design of learning models, starting from planning to arrange curriculum, syllabus and semester course plans (RPS) or lecture event units (SAP), to arranging lecture material for History of Islamic Culture and its studen book. While the application of learning design includes strategy, methods and evaluation. However, this matter, at the level of its application in higher education as mentioned above will be meaningless, unless the SKI lecturer who is responsible for internalizing multicultural values as mentioned above has a high awareness of the values of multiculturalism. Without the SKI lecturers who are aware of multicuralism, the values of multiculturalism will never be internalized in the attitudes and personalities of students as well students.
\end{abstract}

Keyword. A Learning Design; Multicuralism; Internalizing.

Abstrak. Artikel ini berupaya menawarkan sebuah desain pembelajaran Sejarah Kebudayaan Islam berbazis multikultural di Perguruan Tinggi. Nilai-nilai multikultural yang tersebut mencakup sikap menghargai diri, sikap menghargai orang lain, sikap menghargai lingkungan dan alam kultural, sikap menghargai keindahan, sikap menghargai keindahan, dan sikap menghargai keutuhan. Keenam nilai multikulturalisme ini diharapkan diinternalisasikan dalam pembelajaran oleh dosen pengampu matakuliah Sejarah Kebudayaan Islam di Perguruan Tinggi dalam sebuah desains model pembelajaran, mulai dari perencaan menyusun kurikulum, silabus dan rencana perkuliahan semester (RPS) atau satuan acara perkuliahan (SAP), mengatur materi kuliah Sejarah Kebudayaan Islam, sampai menyiapkan bahan ajar yang berwawasan multikultural. Sedangkan penerapan desains pembelajarannya meliputi strategi, metode dan evaluasi. Namun hal ini, pada tataran penerapannya di perguruan tinggi sebagaimana yang tersebut di atas akan tidak bermakna, kecuali jika dosen pengampu matakuliah SKI yang bertanggung jawab menginternalisasi nilai-nilai multikultural sebagaimana yang disebutkan di atas mempunyai kesadaran yang tinggi terhadap nilai-nilai multikulturalisme. Tanpa adanya dosen pengampu matakuliah SKI yang sadar multikuralisme, nilai-nilai multikulturalisme tidak akan pernah terinternalisasikan dalam sikap dan pribadi mahasiswa sebagai peserta didik dengan baik.

Kata kunci. Model Pembelajaran; Multikultural; Internalisasi.

Copyright (C J-PAI: Jurnal Pendidikan Agama Islam. All Right Reserved.

This is an open-access article under the CC BY-SA license

(https://creativecommons.org/licenses/by-sa/4.0/).

Correspondence Address: jpai@uin-malang.ac.id

\section{A. PENDAHULUAN}

Pluralitas dan heterogenitas suku, ras, agama dan golongan telah menjadi cirikhas bangsa ini sejak mula berdirinya negara Indonesia yang diusung dalam satu ikatan: "Bhinneka Tunggal Ika" selayaknya dijunjung tinggi dan dihormati. Namun realitasnya, 
M. Hadi Masruri: Mendesain Model Pembelajaran Sejarah Kebudayaan Islam...

konflik horizontal sering terjadi sepanjang sejarah perjalanannya hingga kini, dan justru dilatarbelakangi oleh isu-isu SARA (Azra, 2005: vi). Agama yang seharusnya menjadi rahmat dan pemersatu antar suku, ras atau golongan, justru sering dianggap sebagai pemicu terjadinya konflik yang berkepanjangan yang bahkan disertai kekerasan, dan pertumpahan darah di hampir semua wilayah di Indonesia, dari Aceh sampai ke Papua.

Salah satu aspek yang paling menonjol untuk diperhatikan mengapa konflik tersebut sering terjadi adalah kurang efektifnya pendidikan agama di sekolah. Dari hasil kajian pelbagai disiplin dan pendekatan, tampaknya ada kesamaan pandangan bahwa segala macam krisis itu berpangkal dari krisis akhlak atau moral. Pendidikan Agama di sekolah-sekolah formal di Indonesia, dinilai oleh banyak kalangan telah gagal dalam mencapai tujuannya. Nilai-nilai moral seperti kejujuran, keadilan dan hormat, empati, simpati dan menolong kaum lemah cenderung diabaikan. Itu semua merupakan bagian dari bentuk kegagalan pendidikan agama. Bahkan, konflik SARA yang terjadi akhir-akhir ini merupakan cerminan dari rendahnya sikap toleransi dan kerukunan beragama. Fenomena tersebut sekaligus merupakan bukti konkrit bahwa pendidikan agama kurang efektif (Rossidy, 2009: 2).

Timbulnya kasus-kasus intoleran dan konflik SARA di masyarakat tersebut memang bukanlah semata-mata karena kegagalan pendidikan agama di sekolah, tetapi bagaimana semuanya itu dapat digerakkan oleh pendidik agama untuk mencermati kembali dan mencari solusi alternatif lewat pengembangan model pembelajaran pendidikan agama untuk tidak hanya berjalan secara konvensional-tradisional.

Mata kuliah Sejarah Kebudayaan Islam (SKI) merupakan salah satu komponen penting dalam pembelajaran pendidikan agama Islam yang diharapkan mampu memberikan gambaran konkrit dan wawasan yang komprehensif tentang kehidupan multicultural yang tercermin dari peristiwa-peristiwa sejarah peradaban Islam.

Dalam catatan sejarah Islam awal digambarkan bagaimana nabi Muhammad saw. tampil sebagai sosok yang kosmopolis yang berhasil membentuk subuah komunitas masyarakat di Madinah yang harmonis, yang terjamin di dalamnya suatu kehidupan pluralis yang multi-kultural. Piagam Madinah dan Perjanjian Makkah menjadi bukti jaminan kehidupan sosial yang menjunjung tinggi perdamaian dan semangat toleransi. Perjanjian Makkah (Hudaibiyyah) menjadi titik yang sangat monumental, karena hal itu justru dilakukan nabi ketika kaum muslimin telah kalah-porak poranda dalam peperangan Uhud, namun tetap dilingkupi semangat juang untuk dapat membalas kekalahan itu, dan kalau dapat dalam waktu yang sedekat mungkin. Tapi nabi Muhammad s.a.w. malah melakukan tindakan sebaliknya, membuat perjanjian dengan pihak musuh, adalah tindakan yang melawan arus. Seiring berjalannya waktu perjanjian Makkah ini menjali awal dan momen untuk perenungan diri, yang tidak saja bagi kaum muslimin, melainkan juga bagi pihak musuh, orang-orang kafir Quraisy. Satu demi satu tokoh-tokoh terdepan Quraisy, yang semula menjadi panglima perang Uhud dan sangat memusuhi Islam justru masuk Islam. Realitas sejarah inilah yang kemudian dipahami oleh kaum muslimin bahwa tindakan nabi melakukan perjanjian Hudaibiyah (Makkah) adalah tindakan yang jitu.

Lebih dari itu, tidak pernah misalnya dalam perjalanan sejarah nabi di Madinah mengusir komunitas kabilah apa pun tanpa adanya alasan krusial, atau melakukan embargo ekonomi, atau bahkan boikot politik terhadap suatu komunitas kabilah atau agama tertentu, termasuk komunitas Yahudi yang notabene sering berbuat rewel dan bahkan seorang Yahudi bernama Abdullah bin Ubay pernah merecoki kehidupan keluarga nabi yang kemudian dikenal dengan hadits el-ifk (al-Mubaarakfuri, 2004: 455). Kehidupan komunitas masyarakat di Madinah adalah gambaran riel dari kehidupan kosmopolitan yang multikultural dan harmonis. 
Oleh karena itu, untuk mengembangkan sikap toleran terhadap golongan lain dan kerukunan hidup beragama, maka perlu dikembangkan sebuah pembelajaran alternatif, yaitu sebuah pembelajaran yang dapat mengarahkan peserta didiknya untuk menjadi seorang yang mempunyai sikap dan wawasan toleransi dan kerukunan yang tinggi sehingga dapat memahami dan menilai kehidupan yang beragam ini secara bijaksana melalui pembelajaran Sejarah Kebudayaan Islam (SKI) berbasis multikultural, terutama di perguran tinggi yang berperan sebagai agen perubahan sosisal, sehingga diharapkan dapat terciptanya sebuah kehidupan bermasyarakat yang damai, toleran dan harmoni. Untuk itu makalah ini hendak mengkaji desains pembelajaran Sejarah Kebudayaan Islam (SKI) berbasis multikultural dan penerapannya di Perguruan Tinggi

Konsep tentang kehidupan multikultural sebenarnya secara sederhana dapat dilacak melalui sebuah kata kunci (key word) pluralitas yang di dalam bahasa arab dikenal dengan al-ta'addudiyyah. Al-ta'addudiyyah berasal dari kata dasar 'adad yang berarti bilangan. Kemudian ta'addad berarti berbilang-bilang, sehingga secara etimologis ta'addudiyyah berarti pluralitas (plurality) (Hans Wehr, 1980: 595). Maka, pluralitas sangat dekat maknanya dengan keragaman dan heterogenitas manusia dalam semua aspek kehidupannya baik sosial, budaya, agama, politik dan ras, adalah realitas aksiomatik yang oleh al-Qur'an sendiri diakui eksistensinya. Misalnya firman Allah: "Dan dari tanda-tanda kekuasan-Nya adalah penciptaan langit dan bumi dan keragaman bahasa dan warnamu (baca: ras). (QS. Al-Rum, 30:22), dan lain sebagainya banyak sekali yang secara tegas disiratkan di dalam al-Qur'an (Huwaidi, 1996).

Sedangkan Multikultural secara etimologis berakar dari kata kultur berasal dari bahasa Inggris culture (Echols, 1996: 159), yang berarti kebudayaan yang mencakup adat istiadat, kebiasaan, cara berpikir, pemahaman keagamaan, dan hasil cipta karya manusia dari aspek immaterial atau intelektual (Mahmud, 1994: 166). Dalam konteks ini, kebudayaan disebut sebagai al-tsaqafah yang berarti kepandaian dan kecerdasan (Majma' al-Lughah al-'Arabiyyah Mesir, 1990). Sehingga pendidikan multi-kultural lebih merupakan upaya membantu orang lain agar memahami, menghayati, dan mengakui adanya keberagaman manusia baik dari aspek rasnya, keberagamaannya, adat-istiadatnya, cara berpikirnya dan lain sebagainya, untuk kemudian diharapkan terciptanya sebuah kehidupan yang harmoni, familier, saling menghormati, dan toleran.

Sebagai sebuah wacana baru, pengertian pendidikan multikultural hingga saat ini belum begitu jelas dan masih menjadi perdebatan di kalangan pakar pendidikan. Namun demikian bukan berarti bahwa pendidikan multikultural dapat didefinisikan atau tidak mempunyai definisi yang jelas. Dan pada hakekatnya sama dengan pendidikan itu sendiri, yang definisinya diperdebatkan antara satu pakar dengan pakar lainnya. Hal yang sama juga terjadi pada interpretasi tentng makna pendidikan multikultural.

Meminjam pendapat Andersen dan Cusher, bahwa pendidikan multikultural dapat diartikan sebagai pendidikan mengenai keragaman kebudayaan. Sementara James Banks mendefinisikan pendidikan multikultural sebagai pendidikan untuk people of color. Dalam pengertian bahwa pendidikan multikultural ingin mengeksplorasi perbedaan sebagai keniscayaan karena dipandang sebagai hukum Tuhan (sunnat Allah). Persoalannya adalah bagaimana kita mampu mensikapi perbedaan tersebut dengan penuh toleran dan semangat egaliter.

Sejalan dengan pemikiran di atas, Muhaemin el Ma'hady berpendapat, bahwa secara sederhana pendidikan multikultural dapat didefinisikan sebagai pendidikan tentang keragaman kebudayaan dan agama dalam merespon perubahan demografis dan kultural di dalam lngkungan masyarakat tertentu, atau bahkan dunia global secara keseluruhan (Choirul Mahfud, 2009: 176). 
M. Hadi Masruri: Mendesain Model Pembelajaran Sejarah Kebudayaan Islam...

Hilda Hernandez mengartikan pendidikan multikultural sebagai perspektif yang mengakui realitas politik, sosial, dan ekonomi yang dialami oleh masing-masing individu dalam pertemuan manusia yang kompleks dan beragam secara kultur, dan merefleksikan pentingnya budaya, ras, seksualitas dan gender, entitas, agama, status sosial, ekonomi, dan pengecualian-pengecualian dalam proses pendidikan (Hilda Hernandez, 1989), atau dengan pengertian lain, bahwa ruang pendidikan sebagai media transformasi ilmu pengetahuan (trasformation of knowledge) hendaknya mampu memberikan nilai-nilai multikulturalisme dengan cara saling menghargai dan menghormati atas realitas yang beragam (plural), baik latarbelakang maupun sosio-budaya yang melingkupinya.

Pemikiran tersebut sejalan dengan pemikiran Paulo Freire, bahwa pendidikan bukan merupakan 'menara gading' yang berusaha menjauhi realitas sosial dan budaya. Pendidikan menurutnya, harus mampu menciptakan tatanan masyarakat yang terdidik dan berpendidikan, bukan sebuah masyarakat yang hanya mengagungkan prestise sosial sebagai akibat kekayaan dan kemakmuran yang dialaminya (Paulo Freire, 2000).

Pendidikan multikultural merupakan respons terhadap perkembangan keragaman populasi sekolah, sebagaimana tuntutan persamaan hak bagi setiap keelompok. Dalam dimensi lain, pendidikan multikultural merupakan pengembangan kurikulum dan aktivitas pendidikan untuk memasuki berbagai pandangan, sejarah, prestasi dan perhatian terhadap orang-orang non-Eropa. Sedangkan secara luas, pendidikan multikultural itu mencakup seluruh siswa tnpa membedakan kelompok-kelompoknya seperti gender, etnik, ras, budaya, strata sosial dan agama.

James Banks (Hilda Hernandez, 1989) menjelaskan, bahwa pendidikan multikultural memiliki beberapa dimensi yang saling berkaitan antara satu dengan yang lain, yaitu: Pertama, Muatan yang integratif (conten integration), yaitu mengintegrasikan berbagai budaya dan kelompok untuk mengilustrasikan konsep mendasar, generasi dan teori dalam mata pelajaran atau disiplin ilmu. Kedua, proses konstruksi pengetahuan (the knowldge contruction process), yaitu membawa siswa untuk memahami implikasi budaya ke dalam sebuah mata pelajaran. Ketiga, pembelajaran yang berkeadilan (an equity paedagogy), yaitu menyesuaikan metode pengajaran dengan cara belajar siswa dalam rangkamemfasilitasi prestasi akademik siswa yang beragam, baik dari segi ras, budaya, ataupun sosial. Keempat, mereduksi prasangka (prejudice reduction), yakni mengidentifikasi karakteristik ras siswa dan menentukan metode pengajaran mereka. Kemudian melatih kelompok untuk berpartisipasi dalam kegiatan pembelajaran, berinteraksi dengan seluruh staff dan siswa yang berbeda etnis dan ras dalam upaya menciptakan budaya akademik yang toleran dan inklusif.

Menurut H.A.R Tilaar, pendidikan multikultural berawal dari berkembangnya gagasan dan kesadaran tentang "interculturalisme" seusai perang Dunia kedua. Gagasan interkulturalisme ini, selain terkait dengan perkembangan politik internasional menyangkut HAM, kemerdekaan dari kolonialisme, dan diskriminasi rasial dan lain sebagainya, juga karena meningkatnya pluralitas di negara-negara Barat sebagai akibat dari peningkatan migrasi dari negara-negara baru merdeka ke Amirika dan Eropa (Tilaar, 2000).

Adapun fokus pendidikan multikultural, menurut Tilaar adalah bahwa dalam program pendidikan multikultural, fokus tidak lagi diarahkan semata-mata kepada kelompok rasial, agama, dan kultural dominan atau mayoritas (mainstreem). Fokus seperti ini pernah menjadi tekanan pada pendidikan interkultural yang meningkatkan pemahaman dan toleransi individu-individu yang berasal dari kelompok minoritas terhadap budaya mainstreem yang dominan, yang pada akhirnya enyebabkan orang-orang dari kelompok minoritas terintegrasi ke dalam masyarakat mainstreem. Pendidikan multikultural 
sebenarnya merupakan sikap "peduli' dan mau mengerti (diference) atau politics of recognition (politik pengakuan terhadap orang-orang dari kelompok minoritas).

Dalam konteks ini, pendidikan multikultural melihat masyarakat secara lebih luas. Berdasarkan pandangan dasar bahwa sikap indiference dan non-recognition tidak hanya berakar dari ketimpangan struktur rasial, tetapi paradigma pendidikan multikultural mencakup subjek-subjek mengenai ketidakadilan, kemiskinan, penindasan dan keterbelakangan kelompok-kelompok minoritas dalam berbagai bidang sosial, budaya, ekonomi, pendidikan dan lain sebagainya. Paradigma seperti ini akan mendorong tumbuhnya kajian-kajian tentang ethnic studies untuk kemudian menemukan tempatnya dalam kurikulum pendidikan sejak dari tingkat dasar sampai perguruan tinggi. Tujuan initi dari pembahasan tentang subjek ini adalah untuk mencapai pemberdayaan bagi kelompokkelompok minoritas dan disadventaged.

Istilah pendidikan multikultural dapat digunakan baik pada tingkat deskriptif dan normatif, yang menggambarkan isu-isu dan masalah pendidikan yang berkaitan dengan masyarakat multikultural. Lebih jauh, istilah ini uga mencakup pengertian tetang pertimbangan terhadap kebijakan-kebijakan dan strategi-strategi pendidikan dalam masyarakat multikultural. Dalam konteks deskriptif ini, kurikulum pendidikan multikultural seharusnya mencakup subjek-subjek seperti: toleransi, tema-tema tentang perbedaan etno-kultural, dan agama-agama, bahaya diskriminasi, penyelesaian konflik dan mediasi, HAM, demokrasi, pluralisme, multikulturalisme, kemanusiaan universal, dan subjek-subjek lain yang relevan.

Dalam konteks teoritis, belajar dari model-model pendidikan multikultural yang pernah ada dan sedang dikembangkan oleh negara-negara maju, dikenal lima pendekatan: pertama, pendidikan mengenai perbedaan kebudayaan atau multikulturalisme. Kedua, pendidikan mengenai pemahaman kebudayaan. Ketiga, pendidikan tentang pluralisme. Keempat, pendidikan dwi-budaya, dan kelima, pendidikan multikultural sebagai pengalaman moral manusia.

Kata "model" secara etimologis diartikan sebagai bentuk mode atau bentuk rupa; bentuk: contoh (Pius A. Partanto, 1994: 476). Sedangkan secara terminilogis kata "model" diartikan sebagai sesuatu yang dianggap benar tetapi bersifat kondisional. Oleh karenanya, model pembelajaran sangat dipengaruhi oleh situasi dan kondisi tempat model itu akan diterapkan beserta penerapan nilai-nilai yang mendasarinya (Muhaimin, 2001: 305). Dari sini, model pembelajaran adalah sesuatu kerangka konseptual yang digunakan sebagai pedoman dalam melakukan sesuatu aktivitas pembelajaran. Agar dapat tercapai tujuantujuan pendidikan, diperlukan model pembelajaran yang efektif dan efisien.

Sarbiran berpendapat bahwa Istilah model digunakan untuk menunjukkan pengertian yang pertama sebagai kerangka konseptual. Atas dasar pemikiran tersebut, maka yang dimaksud dengan "model pembelajaran" adalah kerangka konseptual yang melukiskan prosedur yang sistematis dalam mengorganisasikan pengalaman belajar, untuk mencapai tujuan tertentu, serta berfungsi sebagai pedoman bagi para pendidik dalam suatu proses pembelajaran, dan para instruktur atau pengajar, dalam merencanakan dan melaksanakan aktivitas belajar mengajar (Muslih Usa, 1997: 12).

Suatu model mengajar dapat pula diartikan sebagai suatu rencana atau pola yang digunakan dalam menyusun kurikulum, mengatur materi pengajaran dan memberi petunjuk kepada pengajar di kelas dalam setting pengajaran atau setting lainnya (Zainsyah, 1990: 21).

S.S. Chauhan (Abdul Aziz Wahab, 2008: 52) mengungkapkan tentang salah satu batasan model mengajar yaitu: 
M. Hadi Masruri: Mendesain Model Pembelajaran Sejarah Kebudayaan Islam...

"Model of teaching can be defined as an instructional design which describes the process of specifying and producing particular environmental situations which cause the student to interac in such a way that a specific change occurs in their behavior."

Batasan tentang model mengajar yang dikemukakan oleh Chauhan, menyebutkan bahwa model mengajar merupakan sebuah perencanaan pengajaran yang menggambarkan proses yang ditempuh selama kegiatan belajar mengajar agar tercapai perubahan spesifik pada perilaku siswa seperti yang diharapkan.

Untuk itu, model mengajar merupakan suatu pendekatan yang digunakan oleh guru dalam melaksanakan kegiatan pengajaran. Artinya, pola bagaimana guru melaksanakan proses pengajaran melalui tahapan-tahapan tertentu sehingga siswa dapat mengikuti proses belajar secara sistematis (Nana Sudjana, 1989: 95).

Dalam kaitannya dengan semua mata pelajaran, maka guru dapat mengembangkan model mengajarnya yang dimaksudnya sebagai upaya mempengaruhi perubahan yang baik dalam perilaku peserta didik. Pengembangan model mengajar yang telah dilakukan, bertujuan untuk membantu guru meningkatkan kemampuannya untuk lebih mengenal siswa dan menciptakan lingkungan yang lebih bervariasi bagi kepentingan belajar siswa.

Brenda Watson memaparkan tiga model pembelajaran pendidikan agama yaitu The Confessional model, The Highest Common Factor Model, The Phenomenological Model (Watson, 1993): Pertama, The Confessional model, model Konvensional menggunakan pendekatan tradisional dogmatis yang berupaya mendapatkan iman atau keyakinan agama melalui pendidikan secara doktriner. Agama diajarkan dalam konteks atau tradisi agama tertentu karena agama dianggap membentuk nilai dan keyakinan yang mendasari sebuah masyarakat. Pendukung model ini berasumsi bahwa agama adalah sebuah kebenaran sehingga agama dijadikan titik berangkat (starting point) dalam pembelajaran; Kedua, The Highest Common Factor Model berusaha mencari nilai-nilai yang berkaitan dengan agama yang diterima luas oleh masyarakat termasuk yang tidak mempercayai agama. Karena yang diajarkan adalah nilai-nilai yang bisa diterima oleh masyarakat luas maka model ini tidak banyak menimbulkan kontroversi dibandingkan dengan model pertama yang menuntut siswa memasuki tradisi agama tertentu yang belum tentu dianutnya. Model kedua ini mengharapkan siswa dapat mengembangkan sikap kooperatif dan peduli terhadap keadilan dan agama dijadikan sarana untuk menanggulangi kriminalitas dan meningkatkan stabilitas masyarakat.

Ketiga, Model Fenomenologi menggunakan pendekatan multi keyakinan dengan tujuan untuk mengembangkan sikap toleran dan keterbukaan melalui kajian terhadap berbagai agama dunia. Pendukung model ini berpendapat bahwa tujuan pendidikan agama disamping untuk meningkatkan sikap toleran juga menganggap pentingnya agama dalam pembentukan pribadi. Perlu diketahui bahwa pendidikan agama yang dimaksud oleh model ini adalah pengajaran tentang agama bukan pendidikan agama, dan keempat, Model Pendidikan Agama Esensialis merupakan pendekatan jalan tengah yang memadukan unsur-unsur positif dari model-model sebelumnya dan berusaha memberikan kontribusi tertentu bagi perkembangan peserta didik secara utuh serta memberi kepuasan secara pribadi terhadap keyakinan dan nilai yang dianutnya sekaligus untuk membina sikap toleran terhadap agama-agama yang ada di dunia (Watson, 1993: 38-53).

\section{B. HASIL DAN PEMBAHASAN}

\section{Sejarah Kebudayaan Islam di Perguruan Tinggi}

Sejarah Kebudayaan Islam merupakan perkembangan perjalanan hidup manusia muslim dari masa ke masa dalam usaha bersyariah (beribadah dan bermuamalah) dan berakhlak serta dalam mengembangkan sistem kehidupannya yang dilandasi oleh akidah 
yang oleh karenanya juga disebut dengan Sejarah Peradaban Islam (SPI). Secra etimologis, kebudayaan berasal dari bahasa Sansakerta yaitu buddhayah yang merupakan bentuk jamak dari buddhi (budi atau akal). Budi mempunyai arti akal, kelakuan, dan norma. Sedangkan "daya" berarti hasil karya cipta manusia. Maka, kebudayaan adalah semua hasil karya, karsa dan cipta manusia di masyarakat (http://kbbi.web.id/budaya). Istilah kebudayaan sendiri sering dikaitkan dengan istilah peradaban. Perbedaannya : kebudayaan lebih banyak diwujudkan dalam bidang seni, sastra, religi dan moral, sedangkan peradaban digunakan sebagai lawan hidup nomaden, segala sesuatu yang dihasilkan sebagai konsekwensi hidup secara menetap, yang oleh karenanya senantiasa terkait dengan system sosial, politik, ekonomi, teknologi dan seterusnya. Untuk itu, Kebudayaan Islam merupakan hasil karya, karsa dan cipta umat Islam yang didasarkan kepada nilai-nilai ajaran Islam yang bersumber dari Alqur'an dan sunnah Nabi.

Sejarah Kebudayaan Islam di Perguruan Tinggi merupakan salah satu aspek matakuliah PAI yang menelaah tentang asal-usul, perkembangan, peranan kebudayaan atau peradaban Islam dan para tokoh yang berprestasi dalam sejarah Islam pada masa lampau, mulai dari sejarah masyarakat Arab pra-Islam, sejarah kelahiran dan kerasulan Nabi Muhammad saw, sampai dengan perkembangan Islam di wilayah Nusantara. Secara substansial, matakuliah Sejarah Kebudayan Islam memiliki kontribusi dalam memberikan motivasi kepada peserta didik untuk mengenal, memahami, menghayati sejarah kebudayaan Islam, yang mengandung nilai-nilai kearifan yang dapat digunakan untuk melatih kecerdasan, membentuk sikap, watak, dan kepribadian peserta didik. Tujuan kuliah SKI di Perguruan Tinggi adalah agar peserta didik memiliki kemampuankemampuan sebagai berikut:

a. Membangun kesadaran peserta didik tentang pentingnya mempelajari landasan ajaran, nilai-nilai dan norma-norma Islam yang telah dibangun oleh Rasulullah SAW dalam rangka mengembangkan kebudayaan dan peradaban Islam.

b. Membangun kesadaran peserta didik tentang pentingnya waktu dan tempat yang merupakan sebuah proses dari masa lampau, masa kini, dan masa depan

c. Melatih daya kritis peserta didik untuk memahami fakta sejarah secara benar dengan didasarkan pada pendekatan ilmiah.

d. Menumbuhkan apresiasi dan penghargaan peserta didik terhadap peninggalan sejarah Islam sebagai bukti peradaban umat Islam di masa lampau.

e. Mengembangkan kemampuan peserta didik dalam mengambil ibrah dari peristiwa-peristiwa bersejarah (Islam), meneladani tokoh-tokoh berprestasi, dan mengaitkannya dengan fenomena sosial, budaya, politik, ekonomi, iptek dan seni, dan lain-lain untuk mengembangkan kebudayaan dan peradaban Islam.

\section{Desains Pembelajaran Sejarah Kebudayaan Islam Berbasis Multikultural}

Gambaran tentang konsep pendidikan multikultural di atas meniscayakan adanya desain oprasional pendidikan dalam komunitas peserta didik yang beragam, baik secara etnisitas, ras, warna kulit, gender, strata sosial, bahasa, maupun agama. Desain oprasional pendidikan multikultural mencakup tujuan, muatan (contents), model, sarana prasarana pendidikan. Di sini tidak hendak menjelaskan semua konsep yang dibutuhkan pada tataran oprasional pendidikan multikultural, melainkan hendak menkaji secara lebih mendetail konsep pendidikan agama Islam berbasis multikulralisme.

Pendidikan nasional secara umum, sesui UU No. 20 Tahun 2003 tentang Sistem Pendidikan Nasional, berfungsi mengembangkan kemampuan dan membentuk watak serta peradaban bangsa yang bermartabat dalam rangka mencerdaskan kehidupan bangsa, bertujuan untuk berkembangnya potensi peserta didik agar menjadi manusia yang beriman dan bertakwa kepada Tuhan Yang Maha Esa, berakhlak mulia, sehat, berilmu, 
M. Hadi Masruri: Mendesain Model Pembelajaran Sejarah Kebudayaan Islam...

cakap, kreatif, mandiri, dan menjadi warga negara yang demokratis serta bertanggung jawab. Untuk mencapai tujuan tersebut, salah satu bidang studi yang harus dipelajari oleh peserta didik di madrasah adalah pendidikan agama Islam, yang dimaksudkan untuk membentuk peserta didik menjadi manusia yang beriman dan bertakwa kepada Tuhan Yang Maha Esa serta berakhlak mulia.

Sejarah Kebudayaan Islam (SKI) sebagai salah satu aspek dari mata pelajaran Pendidikan Agama Islam (PAI) yang diajarkan di hampir semua jenjang pendidikan formal dari Sekolah Dasar sampai di Perguruan Tinggi, dari lima aspek, yaitu: Al-Qur'an-Hadis, Akidah, Akhlak, Fikih, dan Sejarah Kebudayaan Islam. Masing-masing mata pelajaran tersebut pada dasarnya saling terkait, isi mengisi dan melengkapi. Alqur'an-Hadis merupakan sumber utama ajaran Islam, dalam arti ia merupakan sumber akidah dan akhlak, syari'ah/fikih (ibadah, muamalah), sehingga kajiannya berada di setiap unsur tersebut. Akidah (Usuluddin) atau keimanan merupakan akar atau pokok agama. Syariah/fikih (ibadah, muamalah) dan akhlak bertitik tolak dari akidah, yakni sebagai manifestasi dan konsekuensi dari akidah (keimanan dan keyakinan hidup). Syari'ah atau lebih tepatnya fikih merupakan sistem norma (aturan) yang mengatur hubungan manusia dengan Allah, sesama manusia dan dengan makhluk lainnya. Akhlak merupakan aspek sikap hidup atau kepribadian hidup manusia, dalam arti bagaimana sistem norma yang mengatur hubungan manusia dengan Allah (ibadah dalam arti khas) dan hubungan manusia dengan manusia dan lainnya (muamalah) itu menjadi sikap hidup dan kepribadian hidup manusia dalam menjalankan sistem kehidupannya (politik, ekonomi, sosial, pendidikan, kekeluargaan, Kebudayaan/seni, iptek, olahraga/kesehatan, dan lainlain) yang dilandasi oleh akidah yang kokoh. Sejarah Kebudayaan Islam merupakan perkembangan perjalanan hidup manusia muslim dari masa ke masa dalam usaha bersyariah (beribadah dan bermuamalah) dan berakhlak serta dalam mengembangkan sistem kehidupannya yang dilandasi oleh akidah.

Secara umum, Pendidikan Agama Islam (PAI) yang salah satu aspeknya adalah Sejarah Kebudayaan Islam (SKI), merupakan salah satu poin penting yang diharapkan mampu mengisi kekosongan matapelajaran Budi Pekerti, yang sekaligus berfungsi sebagai pembentuk karakter (character building) bagi peserta didik, terutama di lingkungan Perguruan Tinggi.

Dalam konteks kajian pendidikan multikultural ini, Sejarah Kebudayaan Islam juga diharapkan mampu memberikan kontribusi yang signifikan pada mencapaian karakter peserta didik yang lebih toleran dan menghargai realitas keragaman yang ada di lingkungannya, karena sejarah merupakan penjelasan dari peristiwa-peristiwa yang terjadi sepanjang perjalanan Islam dari sejak mula diturunkannya kepada Nabi Muhammad saw hingga sekarang. Dari sini, sejarah merupakan inplementasi riel dari ajaran Islam yang menjunjung tinggi semangat perdamaian (salam), torelansi (tasamuh), persamaan (musawat), mengakui perbedaan sebagai ketetapan Tuhan (sunnat Allah), sebagimana tercermin dalah Alqur'an:

"Dan di antara tanda-tanda kekuasan-Nya ialah menciptakan langit dan bumi dan keragaman bahasamu dan warna kulitmu. Sesungguhnya pada yang sedemikian itu benar-benar terdapat tanda-tanda (kekuasan Allah) bagi orang-orang yang mengetahui". (QS. Al-Rum, 30:22)

"Bagimu agamamu, dan bagiku agamaku" (QS. Al-Kafirun, 109:6)

"Hai manusia, sesungguhnya Kami menciptakanmu berupa laki dan perempun, dan menjadikanmu berbangsa-bangsa dan bersuku-suku agar kamu dapat saling mengenal" (QS. Al-Hujurat, 49:13)

"Wahai manusia, sesungguhnya Tuhan kamu adalah satu, dan bapak kamu (asalmu) juga satu, setiap kamu sekalian (manusia) dari Adam, dan Adam (diciptakan)dari 
tanah. Sesunggahnya yang paling mulia di antara kamu adalah yang paling bertaqwa. Tiadalah keutamaan bagi bangsa Arab atas bangsa lain, kecuali karena taqwanya" (Hadits Syarif, diriwayatkan Abu Dawud dan Tirmidzi) (Ibn Bahr, 1968: 229).

Untuk itu, nialai-nilai multikulturalisme sebagaimana yang disebutkan di atas perlu diinternalisasikan dalam pembelajaran matakuliah Sejarah Kebudayaan Islam untuk tujuan melatih dan membangun karakter siswa agar mampu bersikap humanis, pluralis, toleran dalam lingkungan mereka. Dengan pengertian lain, melalui internalisasi nilai-nilai multikulturalisme, peserta didik diharapkan dapat dengan mudah memahami, menguasi dan mempunyai kompetensi yang baik terhadap matakuliah Sejarah Peradaban Islam, sekaligus juga mampu untuk selalu bersikap dan menerapkan nilai-nilai multikulturalisme dan pluralisme di lingkungan perguruan tinggi maupun di luar perguruan tinggi.

Dari sini, dapat dirumuskan, bahwa pembelajaran Sejarah Peradaban Islam berbasis multikultural mempunyai dua tujuan, yakni tujuan awal dan tujuan akhir. Tujuan awal merupakan tujuan sementara karena tujuan ini hanya berfungsi sebagai perantara agar tujuan akhirnya dapat dicapai dengan baik.

Tujuan awal pembelajaran Sejarah Kebudayaan Islam berbasis multikultural adalah untuk membangun wacana tentang multikulturalisme di kalangan dosen, ahli pendidikan, pengambil kebijakan dalam dunia pendidikan maupun peserta didik secara umum di Perguruan Tinggi. Harapannya adalah apabila mereka memiliki wacana multikultural yang baik maka kelak mereka tidak hanya mampu membangun kecakapan dan keahlian peserta didik terhadap matakuliah yang diajarkannya, bahkan juga mampu untuk menjadi transformator nialai-nilai multikulturalisme yang mampu menanamkan nilai-nilai pluralisme dan humanisme secara langsung di Perguruan Tinggi kepada peserta didiknya.

Sedangkan tujuan akhir pembelajaran Sejarah Kebudayaan Islam berbasis multikultural ini adalah agar peserta didik tidak hanya mampu memahami dan menguasai matakuliah Sejarah Kebudayaan Islam saja, akan tetapi juga diharapkan peserta didik mempunyai karakter yang kuat untuk selalu bersikap pluralis dan humanis melalui pembacaan dan pengambilan suritaoladan dari peristiwa-peristiwa penting sepanjang sejarah Islam.

Adapun nilai-nilai multikulturalisme yang harus diinternalisasikan ke dalam matakuliah Sejarah Kebudayaan Islam dapat diidentifikasi melalui penanaman enam sikap dasar kepada peserta didik. Enam sikap dasar tersebut sebagaimana ditulis oleh Imron Rossidy (2009: 94-95), yaitu sebagai berikut:

Pertama, sikap menghargai diri. Peserta didik diajak untuk mengembangkan sikap ini dengan beberapa cara antara lain: (1) melakukan refleksi secara konstruktif tentang agama tanpa prasangka; (2) memahami berbagai asumsi tentang agama yang ada di lingkungannya dan masyarakat pada umumnya tanpa secara otomatis menolaknya; (3) mengembangkan kepercayaan terhadap segi positif pemahaman penganut agama lain dan melengkapinya dengan sikap yang seimbang serta terbuka; dan (4) mengembangkan keinginan untuk merevisi pikiran dan perasaan tentang agama.

Kedua, sikap menghargai orang lain. Peserta didik diajak untuk melakukan beberapa kegiatan yang dapat mengembangkan sikap ini, antara lain: (1) menghargai kelebihan agama lain dan mampu memahami dinamika orang beragama; (2) menghargai aneka pengalaman dan argumentasi yang mendasari keyakinan penganut agama; (3) mempelajari bahasa afirmasi (dukungan atau persetujuan) secara fasih sekaligus menghargai sesuatu yang dianggap bermakna atau penting bagi penganut agama lain.

Ketiga, sikap menghargai lingkungan dan alam kultural. Peserta didik diajak untuk melakukan dua hal yang bisa mengembangkan sikap ini, yaitu: (1) menghargai keragaman tanpa menyerang kelemahan yang diidap oleh penganutnya; dan (2) mampu menghargai 
M. Hadi Masruri: Mendesain Model Pembelajaran Sejarah Kebudayaan Islam...

seseorang tanpa menyingkirkan ketaatannya serta memahami dasar-dasar mufakat antar tradisi agama.

Keempat, sikap menghargai keindahan. Peserta didik dapat diajak untuk mengembangkan sikap ini dengan dua jalan, yaitu: (1) mengembangkan kemampuan berimajinasi yang dapat menumbuhkan visi dan memahami berbagai ekspresi agama; dan (2) menghargai kekuatan emosi para penganut yang taat dan memahami bahwa kekuatan emosi tersebut bisa mengarah kepada sesuatu yang bermanfaat atau berbahaya.

Kelima, sikap menghargai kebenaran. Peserta didik dapat diajak untuk menghargai kebenaran tentang makna dan tujuan hidup dengan beberapa cara antara lain: (1) mengembangkan sikap menantang asusmsi para sekularis dan menghargai klaimkebenaran dari para penganut agama yang tidak mudah dihilangkan; (2) memahami kekhususan agama, menyadari adanya aneka cara yang berkedok agama; (3) menghargai sifat-sifat agama yang controversial; (4) memahami cara-cara menilai perwujudan agama dalam praktik dengan kriteria yang tepat; dan (5) menghargai rambu-rambu yang terkait dengan pemberian batas wilayah agama dan non-agama.

Keenam, sikap menghargai keutuhan. Peserta didik dapat diajak untuk mengembangkan sikap menghargai keutuhan (bukan berat sebelah atau sempalan), yaitu dengan cara antara lain: (1) meningkatkan kemampuan dan kemauan untuk melakukan refleksi tentang totalitas pengalaman kehidupan dan berbagai pandangan yang ditemui; (2) mampu menghargai keterkaitan atas segala sesuatu yang terjadi di luar sekolah dengan sesuatu yang dipelajari di sekolah; (3) menghargai tantangan berat yang dihadapi agama yang menganggap bahwa ilmu hanya bisa diperoleh dengan rasio dan proses eksperimentasi ilmiah; dan (4) peduli dengan keyakinan agama sekaligus terbuka dengan temuan bukti dan pengalaman.

\section{KESIMPULAN}

Dalam perspektif Islam, multikulturalisme berakar pada terma pluralisme, dalam pengertian bahwa Islam memandang keberagaman suku, bangsa, bahasa, budaya dan agama sebagai realitas, bahkan menjadikannya sebagai media untuk saling mengenal, menghormati, dan menghargai agar tercipta sebuah kehidupan yang tentram, toleran, dan damai sesuai dengan terminologi Islam sebagai agama damai. Konsep Islam tentang multikulturalisme secara eksplisit dinyatakan dalam ayat-ayat Alqur'an dan hadis Nabi, yang secara garis besarnya mencakup: sikap menghargai diri, sikap menghargaioranglain, sikap menghargai lingkungan dan alam kultural, sikap menghargai keindahan, sikap menghargai keindahan, dan sikap menghargai keutuhan.

Keenam nilai multikulturalisme inilah yang kemudian diharapkan dapat diinternalisasikan dalam pembelajaran oleh dosen pengampu matakuliah Sejarah Kebudayaan Islam di Perguruan Tinggi dalam sebuah desains model pembelajaran, baik dari aspek perencaan dalam menyusun kurikulum yang meliputi penyusunan silabus dan rencana perkuliahan semester (RPS) atau satuan acara perkuliahan (SAP), mengatur materi kuliah Sejarah Kebudayaan Islam sampai menyiapkan bahan ajar yang berwawasan multikultural. Sedangkan penerapan desains pembelajarannya meliputi strategi, metode dan evaluasi.

Desain pembelajaran Sejarah Kebudayaan Islam berbazis multikultural pada tataran penerapannya di perguruan tinggi sebagaimana yang tersebut di atas akan tidak bermakna, kecuali jika dosen pengampu matakuliah SKI yang bertanggung jawab menginternalisasi nilai-nilai multikultural sebagaimana yang disebutkan di atas mempunyai kesadaran yang tinggi terhadap nilai-nilai multikulturalisme. Tanpa adanya dosen pengampu matakuliah SKI yang sadar multikuralisme, nilai-nilai multikulturalisme tidak akan pernah terinternalisasikan dalam sikap dan pribadi mahasiswa sebagai peserta didik dengan baik. 
DAFTAR PUSTAKA

Ali, Muhamad. 2003. Teologi Pluralis-Multikultural: Menghargai Kemajemukan Menjalin Kebersamaan. Jakarta, Kompas.

Azra, Azyumardi. 2005. "Pendidikan Agama: Membangun Multikulturalisme Indonesia" Pengantar dalam Zakiyuddin Baidhawy, Pendidikan Agama Berwawasan Multikultural. Jakarta: Erlangga.

Echols, John M. dan Hassan Shadily. 1996. Kamus Inggris Indonesia. Jakarta: PT. Gramedia Pustaka Utama.

Freire, Paulo. 2000, Pendidikan Pembebasan. Jakarta: LP3S.

Hans Wehr. 1980. Mu'jam al-Lughah al-'Arabiyyah al-Mu'ashirah. Beirut: Maktabat Lubnan.

Hernandez, Hilda. 1989. Multicultural Education: A Teacher Guide to Linking Context, Process, and Contents. New Jersey \& Ohio: Prentise Hall.

Huwaidi, Fahmi. 1996. Al-Muftarun: Khitab al-Tatharruf al-'Ilmani fi al-Mizan. Beirut: Dar al-Syuruq.

Mahfud, Choirul. 2009. Pendidikan Multikultural. Yogyakarta: Pustaka Pelajar.

Mahmud, 'Ali Abd al-Halim. 1994. Al-Taraju' al-Hadlari fi al-'Alam al-Islami Mesir: Dar alWafa'.

Majma' al-Lughah al-'Arabiyyah Mesir. 1990. Al-Mu'jam al-Washith. Istanbul: Dar alDa'wah.

Mubaarakfuri-al, Shafiyy al-Rahman. 2004. Perjalanan Hidup Rasul yang Agung Muhammad: Dari Kelahiran Hingga Detik-detik Terakhir, terjemahan Hanif Yahya, Tt: Darussalam.

Muhaimin. 2001. Paradigma Pendidikan Islam. Bandung: PT. Remaja

Partanto, Pius A. dan M. Dahlan al-Barry, 1994. Kamus Ilmiah Populer. Surabaya: Arkola.

Rossidy ,Imron. 2009. Pendidikan Berparadigma Inklusif, Malang, UIN Malang Press.

Tilaar, H.A.R. 2000. Perubahan Sosial dan Pendidikan: Pengantar Pedagogik Transformatif untuk Indonesia. Jakarta: Grasindo.

Usa, Muslih. 1997. Pendidikan Islam dalam Peradaban Industrial. Yogyakarta: Aditya Media.

Wahab, Abdul Aziz. 2008. Metode dan Model-model Mengajar. Bandung: Alfabeta.

Watson, Brenda. 1993. The Efective Teaching of Religious Education. London New York: Longman.

Zainsyah, A.E. dkk. 1990. Model-Model Mengajar. Bandung: CV. Diponegoro. 